\title{
Rotihibins, Novel Plant Growth Regulators from Streptomyces graminofaciens
}

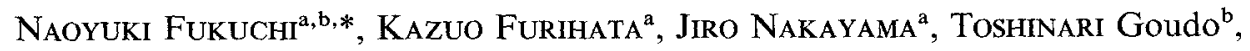 \\ SEIJI TAKAYAMA ${ }^{b, \dagger}$, AKIRA IsOgaI ${ }^{a, \dagger}$ and AKINORI SUZUKI ${ }^{a}$ \\ ${ }^{a}$ Department of Agricultural Chemistry, The University of Tokyo, \\ Bunkyo-ku, Tokyo 113, Japan \\ ${ }^{\mathrm{b}}$ Central Research Laboratories, AJINOMOTO Co., Inc., \\ Kawasaki-shi, Kanagawa 210, Japan
}

(Received for publication January 26, 1995)

\begin{abstract}
In the course of screening search for plant growth regulators, a culture filtrate of Streptomyces graminofaciens $3 \mathrm{C} 02$ was found to inhibit the growth of lettuce seedlings. The active substances, named rotihibin A (1) and B (2), were revealed to be lipo-peptidal compounds. Rotihibins inhibit growth of various plants at below $1 \mu \mathrm{g} / \mathrm{ml}$, but do not show lethal activity even at higher doses.
\end{abstract}

In our screening search for plant growth regulators from bacterial origin, we found a strain of actinomycete, identified as Streptomyces graminofaciens, that yielded strong plant growth regulators. Based on spectroscopic data, the active substances were revealed to be lipopeptidal compounds, named rotihibin A (1) and B (2) and we reported their structures preliminarily ${ }^{1,2)}$. This paper describes the taxonomy of producing strain, isolation, structural elucidation and biological activity of rotihibins in detail.

\section{Taxonomy of the Producing Strain}

The strain $3 \mathrm{C} 02$ was isolated from a soil sample collected in Bunkyo-ku, Tokyo, Japan. Both substrate and aerial mycelia were formed abundantly on International Streptomyces Project (ISP) media No. 2 (yeast extract - malt extract agar), No. 3 (oatmeal agar) and No. 4 (inorganic salt - starch agar). Morphological observation of cultures grown on the above three media was made by electron microscopy (Fig. 1). Spore chains were monopodial and showed spiral to open-spiral style with 10 to 50 spores in each chain. Mature spores were cylindrical and $1 \times 2 \mu \mathrm{m}$ in size. Spore surfaces were warty. Fragmentation of substrate, sporangia, motile spores were not observed.

Strain 3C02 grew well on most test media shown in Table 1. No diffusible pigment was formed in any tested medium. White to yellowish-gray aerial mycelium was formed on most test media except for sucrose-nitrate

Fig. 1. Scanning electron microphotography of aerial mycelia of strain $3 \mathrm{CO} 2$.

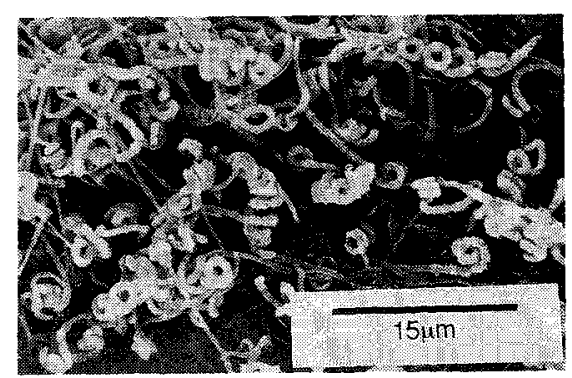

Table 1. Cultural characteristics of strain $3 \mathrm{C} 02$.

\begin{tabular}{llll}
\hline \multicolumn{1}{c}{ Medium } & Growth & Aerial mycelium & Substrate mycerium \\
\hline Sucrose - nitrate agar & Very good & None & Yellowish grey \\
Glucose - asparagine agar & Good & Modrate; white & Yellowish grey \\
Glycerol - asparagine agar (ISP No. 5) & Poor & Scant; white to grey & Colorless \\
Inorganic salt - Starch agar (ISP No. 4) & Good & Abundant; white to light grey & Colorless to yellow \\
Tyrosine agar (ISP No. 7) & Poor & Moderate; white & Colorless to yellowish grey \\
Peptone - yeast extract iron agar (ISP No. 6) & Moderate & None & Colorless to yellowish grey \\
Yeast extract - malt extract agar (IPS No. 2) & Good & Abundant; white & Colorless to pale yellowish \\
Oatmeal agar (ISP No. 3) & Good & Abundant; whilte to light grey & Yellowish grey
\end{tabular}

$\dagger$ Present address: Graduated School of Biological Science, Nara Institute of Science and Technology, Ikoma-shi, Nara 630-01, Japan. 
agar and peptone-yeast extract - iron agar (ISP No. 6) media. The substrate mycelium was colorless to yellowish - gray.

Cell wall analysis of the strain $3 \mathrm{CO} 2$ as described by YAMAGUCHI $^{3)}$ showed that the isomer of diaminopimelic acid contained in the hydrolysate of whole-cell was LL-form.

According to Bergey's Manual of Determinative Bacteriology 4), the physiological characteristics of the strain 3C02, as shown in Table 2, placed it in Streptomyces graminofaciens.

\section{Isolation and Purification}

In the course of purification, activity was monitored by growth inhibition assay with lettuce (Lactuca sativa) seedlings. The strain 3C02 was cultured in Bennett's medium $^{5)}$ with 5 liter volume Erlenmeyer flasks ( 2 liters in each flask) for 4 days at $26^{\circ} \mathrm{C}$. The cultured broth was filtered with celite and the filtrate was adsorbed on Amberlite XAD-7 column and was eluted with 50\% methanol. After the purification of this $50 \%$ methanolic eluate by SP-Sephadex C-25 ion exchange column, the active substances were further purified by reverse-phase HPLC with an octadodecyl silica gel column, SSC-ODS-

Table 2. Physiological characteristics of strain $3 \mathrm{C} 02$

\begin{tabular}{lc}
\hline Liquefaction of gelatin & - \\
Hydrolysis of starch & + \\
Milk coagulatin & - \\
Milk peptonization & - \\
Melanoid production & $10 \sim 40^{\circ} \mathrm{C}$ \\
Temperature & $20 \sim 40^{\circ} \mathrm{C}$ \\
Growth range & \\
Optimal growth & + \\
Utilization of: & + \\
L-Arabinose & + \\
D-Xylose & + \\
D-Glucose & + \\
D-Fructose & + \\
Sucrose & + \\
Inositole & + \\
L-Rhamnose & + \\
Raffinose & + \\
D-Mannitol & + \\
\hline
\end{tabular}

Table 3. Physicochemical properties of rotihibin A (1).

\begin{tabular}{ll}
\hline Molecular formula & $\mathrm{C}_{35} \mathrm{H}_{63} \mathrm{~N}_{11} \mathrm{O}_{13}$ \\
High-resolution FAB-MS & 846.4596 \\
Calcd for $(\mathrm{M}+\mathrm{H})^{+}$ & 846.4685 \\
IR $\mu_{\max }(\mathrm{KBr}) \mathrm{cm}^{-1}$ & $3300,2940,1650,1540,1200$, \\
& 1135 \\
Color reaction & Positive: ninhydrine (orange) \\
Rf value & $0.23 \mathrm{BuOH}-\mathrm{AcOH}-\mathrm{H}_{2} \mathrm{O}$ \\
& $(4: 1: 1)$ \\
UV spectrum & End absorption \\
\hline
\end{tabular}

a Silicagel TLC (Merck Art. No. 5717).
$742(10 \times 250 \mathrm{~mm})$ eluted by $0.1 \%$ trifluoroacetic acid (TFA) with acetonitrile gradient. The active substances named rotihibin $A(1)(52.9 \mathrm{mg})$ and $B(2)$ (small amount) were then obtained as an amorphous white powder.

\section{Structural Elucidation}

Physicochemical properties of rotihibin A (1) were as shown in Table 3. The typical absorption at 1650 and

Table $4 .{ }^{13} \mathrm{C}$ and ${ }^{1} \mathrm{H}$ NMR of rotihibin A (1).

\begin{tabular}{|c|c|c|c|}
\hline & Position & $\begin{array}{c}\delta_{\mathrm{H}} \\
\text { (multiplicity } \\
J(\mathrm{~Hz}))\end{array}$ & $\delta_{\mathrm{C}}$ \\
\hline \multirow{10}{*}{$\begin{array}{l}\text { 2-Decenoic } \\
\text { acid }\end{array}$} & 1 & & 165.7 \\
\hline & 2 & $5.88(\mathrm{~d}, 11)$ & 122.5 \\
\hline & 3 & $5.94(\mathrm{~m})$ & 144.6 \\
\hline & 4 & $2.52(\mathrm{~m}), 2.65(\mathrm{~m})$ & 29.6 \\
\hline & 5 & $1.33(\mathrm{~m})$ & 28.6 \\
\hline & 6 & $1.25(\mathrm{~m})$ & 28.9 \\
\hline & 7 & $1.25(\mathrm{~m})$ & 28.5 \\
\hline & 8 & $1.25(\mathrm{~m})$ & 31.1 \\
\hline & 9 & $1.25(\mathrm{~m})$ & 22.0 \\
\hline & 10 & $0.85(t, 7)$ & 13.8 \\
\hline \multirow[t]{9}{*}{$\mathrm{Cit}$} & 1 & & 172.0 \\
\hline & 2 & $4.36(\mathrm{~m})$ & 52.0 \\
\hline & 3 & $1.49(\mathrm{~m}), 1.60(\mathrm{~m})$ & 27.8 \\
\hline & 4 & $1.33(\mathrm{~m})$ & 26.5 \\
\hline & 5 & $2.94(\mathrm{~m})$ & 26.5 \\
\hline & $2-\mathrm{NH}$ & $8.08(\mathrm{~d}, 8)$ & \\
\hline & $5-\mathrm{NH}$ & $5.96(\mathrm{~m})$ & \\
\hline & $\mathrm{CO}$ & & 158.7 \\
\hline & $\mathrm{NH}_{2}$ & $5.38(\mathrm{~s})$ & \\
\hline \multirow{5}{*}{ Ser } & 1 & & 170.8 \\
\hline & 2 & $4.36(\mathrm{~m})$ & 54.6 \\
\hline & 3 & $3.57(\mathrm{~m})$ & 61.6 \\
\hline & $2-\mathrm{NH}$ & $8.10(\mathrm{~d}, 8)$ & \\
\hline & $3-\mathrm{OH}$ & $5.13(t, 5)$ & \\
\hline \multirow[t]{6}{*}{ Dab } & 1 & & 170.8 \\
\hline & 2 & $4.26(\mathrm{dd}, 7,13)$ & 51.3 \\
\hline & 3 & $1.73(\mathrm{~m})$ & 30.9 \\
\hline & 4 & $3.18(\mathrm{~m})$ & 35.8 \\
\hline & $2-\mathrm{NH}$ & $8.34(\mathrm{~d}, 7)$ & \\
\hline & $4-\mathrm{NH}_{2}$ & $8.40(\mathrm{t}, 5)$ & \\
\hline \multirow[t]{7}{*}{ HyAsn } & 1 & & 168.7 \\
\hline & 2 & $4.55(\mathrm{dd}, 3,9)$ & 55.4 \\
\hline & 3 & $4.30(\mathrm{dd}, 3,6)$ & 70.9 \\
\hline & 4 & & 173.1 \\
\hline & $2-\mathrm{NH}$ & $7.56(\mathrm{~d}, 9)$ & \\
\hline & $3-\mathrm{OH}$ & $5.83(\mathrm{~d}, 6)$ & \\
\hline & $4-\mathrm{NH}_{2}$ & $\begin{array}{l}7.18(\mathrm{~d}, 2), \\
7.28(\mathrm{~d}, 2)\end{array}$ & \\
\hline \multirow{7}{*}{ Asnol } & 1 & & 172.7 \\
\hline & 2 & $\begin{array}{l}2.22(\mathrm{dd}, 7,15) \\
2.38(\mathrm{~m})\end{array}$ & 36.4 \\
\hline & 3 & $4.01(\mathrm{~m})$ & 48.6 \\
\hline & 4 & $3.32(\mathrm{~m})$ & 62.4 \\
\hline & $1-\mathrm{NH}_{2}$ & $\begin{array}{l}6.88(\mathrm{~d}, 1) \\
7.37(\mathrm{~d}, 1)\end{array}$ & \\
\hline & $3-\mathrm{NH}$ & $7.42(\mathrm{~d}, 8)$ & \\
\hline & $4-\mathrm{OH}$ & $4.70(t, 5)$ & \\
\hline \multirow[t]{6}{*}{ aloThr } & 1 & & 166.4 \\
\hline & 2 & $3.69(\mathrm{~d}, 5)$ & 57.6 \\
\hline & 3 & $4.04(\mathrm{~m})$ & 64.8 \\
\hline & 4 & $1.05(\mathrm{~d}, 7)$ & 17.7 \\
\hline & $2-\mathrm{NH}_{2}$ & 7.97 (br.) & \\
\hline & $3-\mathrm{OH}$ & $5.51(\mathrm{~d}, 4)$ & \\
\hline
\end{tabular}


$1540 \mathrm{~cm}^{-1}$ in the IR spectrum and the signals derived from amide $-\mathrm{CONH}$ - in the NMR spectra in DMSO- $d_{6}$ of 1 suggested its peptidal structure. Amino acid analysis of the hydrolysate of 1 by $6 \mathrm{~N} \mathrm{HCl}\left(110^{\circ} \mathrm{C}, 20\right.$ hours $)$ indicated the presence of serine (Ser), allothreonine (alloThr), 2,4-diaminobutanoic acid (Dab), ornithine (Orn) and some unknown amino acids. Edman's degradation of 1 yielded phenylthiohydantoin (PTH)alloThr in the first cycle, but no PTH derivatives were given after the second cycle. High-resolution FAB mass spectra of rotihibin A (1) and $\mathrm{B}(2)$ gave $(\mathrm{M}+\mathrm{H})^{+}$ions at 846.4596 (calcd. for $\mathrm{C}_{35} \mathrm{H}_{64} \mathrm{~N}_{11} \mathrm{O}_{13}, 846.4685$ ) and 847.4593 (calcd. for $\mathrm{C}_{35} \mathrm{H}_{63} \mathrm{~N}_{10} \mathrm{O}_{14}, 847.4529$ ), respectively.

${ }^{1} \mathrm{H}$ - and ${ }^{13} \mathrm{C}-\mathrm{NMR}$ spectra (Table 4 ) of $\mathbf{1}$ indicated that 1 consisted of serine, 2,4-diaminobutanoic acid, allothreonine, 2-decenoic acid and three more residues. ${ }^{1} \mathrm{H}$ COSY, ${ }^{13} \mathrm{C}_{-}{ }^{1} \mathrm{H}$ COSY and $\mathrm{HMBC}^{6)}$ spectra of $\mathbf{1}$ revealed that ornithinyl residue detected in amino acid analysis existed as citllurinyl (Cit) residue in $\mathbf{1}$, and the other two residues were $\beta$-hydroxyasparagine (HyAsn) and 3-amino-4-hydroxybutanamide (asparaginol, Asnol) as shown in Fig. 2. The distinction between hydroxy $-\mathrm{OH}$ protons and all amide protons including urea $-\mathrm{N} H \mathrm{CONH}_{2}$ proton in Cit residue and $-\mathrm{CONH}_{2}$ protons in HyAsn and Asnol residues was confirmed by

Fig. 2. Assignment of the protons and the carbons of hydroxyasparagine (HyAsn) and asparaginol (Asnol) residues in the ${ }^{1} \mathrm{H}$ and ${ }^{13} \mathrm{C}$ NMR spectra of 1 .

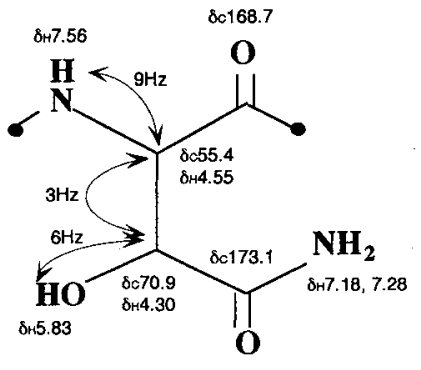

HyAsn

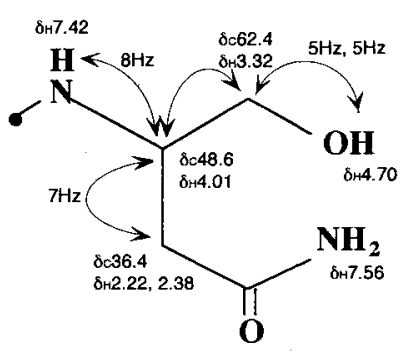

Asnol

Arrows represent the ${ }^{1} \mathrm{H}-{ }^{1} \mathrm{H}$ coupling constants.

${ }^{15} \mathrm{H}^{-1} \mathrm{H}^{\mathrm{HMQC}}{ }^{7)}$ spectrum of 1 . The sequence of these seven residues in 1 was clarified by NOESY and HMBC spectra as shown in Fig. 3, satisfying the molecular formula observed in high-resolution FAB mass spectrum. Furthermore, this structure was consistent with the result in Edman's degradation mentioned above.

To confirm the structure of $\mathbf{1}$ and to elucidate the structure of 2, FAB mass and mass/mass spectra of 1 and $\mathbf{2}$ were analyzed. In the mass/mass spectrum of $\mathbf{1}$, typical sequential fragment ions ${ }^{8)}$ were observed as shown in Fig. 4. The fragment ion pattern of 2 was similar to that of $\mathbf{1}$, but the mass number of $\mathrm{C}$-terminal ions, $\mathrm{Y} 2, \mathrm{Y} 3$ and $\mathrm{Y}^{8}{ }^{8}$ were larger than those of 1 by one mass unit besides $\mathrm{Y} 1$ ions of both molecule were equal. This indicated that $-\mathrm{CONH}_{2}$ group of HyAsn residue in $\mathbf{1}$ was exchanged for $-\mathrm{COOH}$ group in $\mathbf{2}$.

Determination of the stereochemistry of amino acid residues was performed by method of MARFEY ${ }^{9)}$. The hydrolysate of 1 by $6 \mathrm{~N} \mathrm{HCl}\left(110^{\circ} \mathrm{C}, 18\right.$ hours $)$ was reacted with an optically active fluorobenzene derivative, $N$-(3-fluoro-4,6-dinitrophenyl)-L-alaninamide (FDAA), and the reaction mixture was analyzed by HPLC with reverse-phase column. The retention times of each amino acids were compared with the standard samples from L- and DL-amino acids. L- and DL-Aspol (3-amino-4hydroxybutanoic acid) were prepared by reduction of $t$ butyloxycarbonylasparagine (t-Boc Asn). As the results, Ser, Dab, alloThr and Asnol residues were proved to be L-form and Cit residue to be D-form. HyAsp, which was yielded from HyAsn residue was determined to be Lthreo form by the same analysis. The configuration of decenoic acid in 1 was proved to be $Z$ form by the coupling constant between $\mathrm{C}-2$ and $\mathrm{C}-3$ protons (11 ppm).

\section{Biological Activity of Rotihibin A}

Rotihibin A (1) did not show antimicrobial activity against any bacterial or fungal strain tested as shown in Table 5, and did not show cytotoxic activity to K562, FM3A and HSG cells at $200 \mu \mathrm{g} / \mathrm{ml}$.

The inhibitory activity of $\mathbf{1}$ against lettuce seedlings

Fig. 3. Structure of 1 with observed NOEs (arrows) and ${ }^{13} \mathrm{C}-{ }^{1} \mathrm{H}$ long-range couplings (dashed arrows).

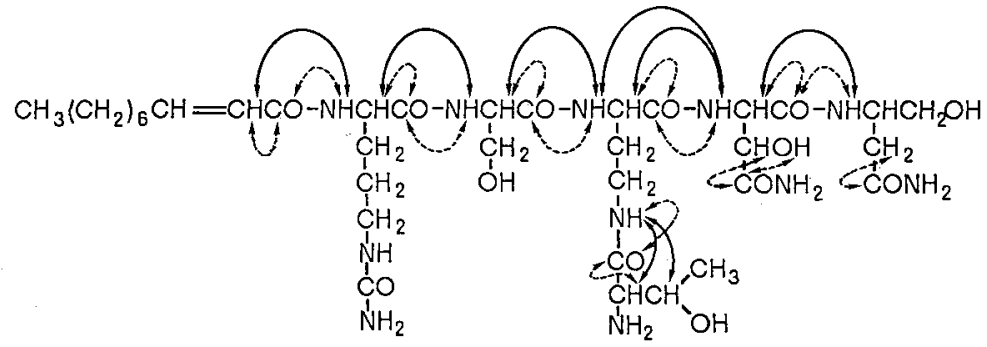


Fig. 4.

(A) Collision activated desorption (CAD) spectrum of $(\mathrm{M}+\mathrm{H})^{+}$ion of 1.

Table shows the comparison between the CAD ions of $\mathbf{1}$ and 2 .

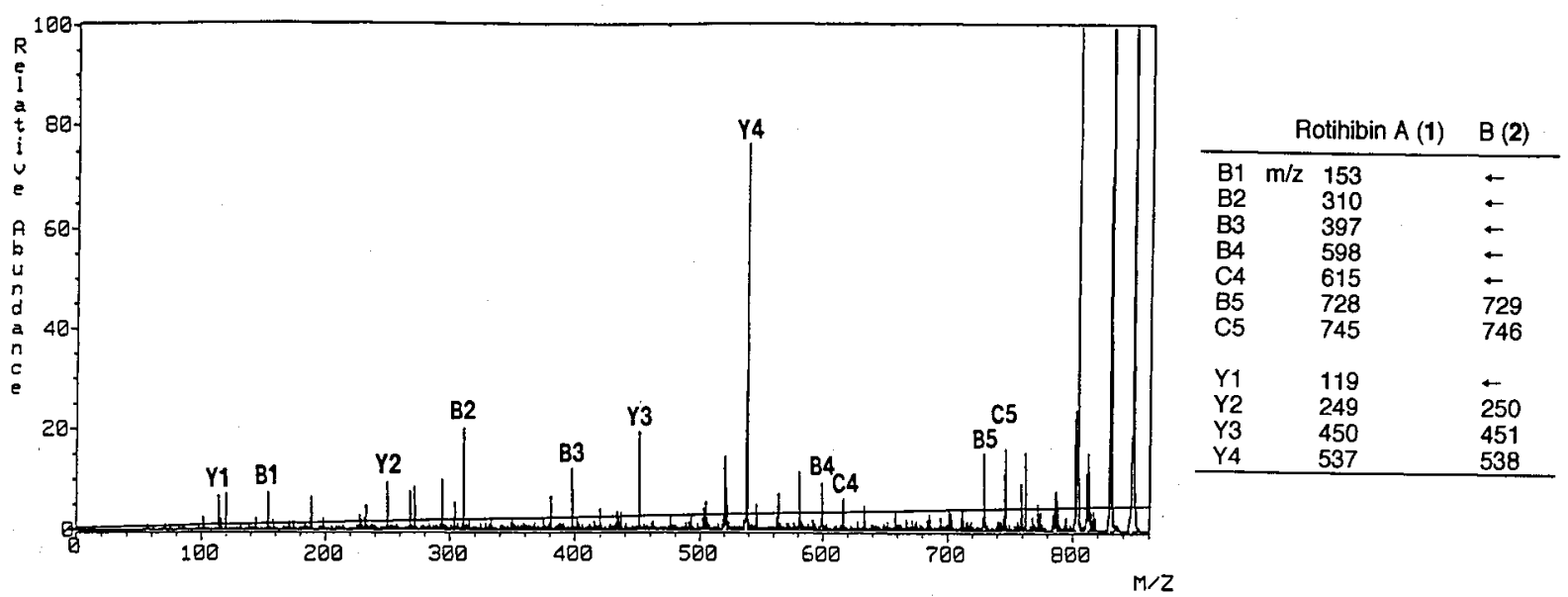

(B) Fragment ion patterns of $\mathbf{1}$ and 2.

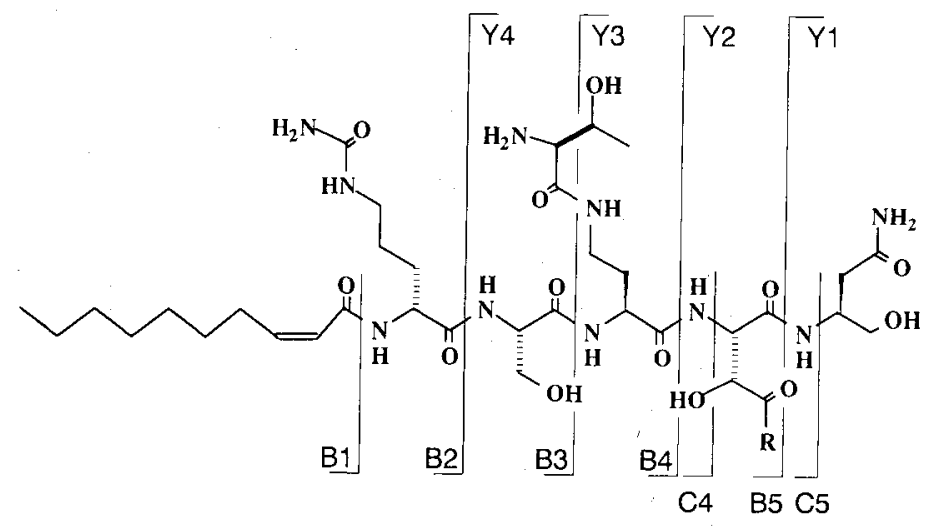

Rotihibin $\mathrm{A}$ (1) $\quad \mathrm{R}=\mathrm{NH}_{2}$

$\mathrm{B}(\mathbf{2}) \quad \mathrm{R}=\mathrm{OH}$

Table 5. Antibiotic activity of rotihibin A (1).

\begin{tabular}{lcc}
\hline \multicolumn{1}{c}{ The organism } & Medium & MIC $(\mu \mathrm{g} / \mathrm{ml})$ \\
\hline Pyricuraia oryzae & $\mathrm{C}$ & $>100$ \\
Botrytis cinerea & $\mathrm{C}$ & $>100$ \\
Fusarium oxysporum & $\mathrm{C}$ & $>100$ \\
Aspergillus oryzae & $\mathrm{C}$ & $>100$ \\
Phytophthora capsici & $\mathrm{C}$ & $>100$ \\
Candida albicans & $\mathrm{P}$ & $>100$ \\
Bacillus subtilis & $\mathrm{N}$ & $>100$ \\
Staphylococcus aureus & $\mathrm{N}$ & $>100$ \\
Xantomonas oryzae & $\mathrm{X}$ & $>100$ \\
Pseudomonas glumae & $\mathrm{N}$ & $>100$ \\
\hline
\end{tabular}

Media C: Czapeck YE agar, P: PDA agar, N: Nutrient agar, X: Medium for Xantomonas.
Fig. 5. Inhibitory activity of $\mathbf{1}$ to the lettuce seedlings.

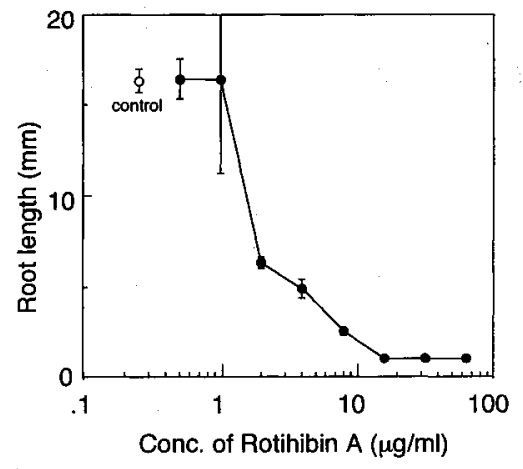

was observed above $1 \mu \mathrm{g} / \mathrm{ml}$ (Fig. 5), but was not lethal at $100 \mu \mathrm{g} / \mathrm{ml}$, and furthermore, the absence of lethality of 1 to the plant was shown by the fact that lettuce seedlings which were treated by $\mathbf{1}$ for two days recovered their normal growth after removal of 1 (Fig. 6).

The activity of 1 against Nicotiana rustica (tobacco) 
Fig. 6. Growth recovery of lettuce seedlings after removal of 1 .

- Treatment of 1 during shaded period ( $2 \sim 4$ days) $\circ$ Treatment of 1 throughout the experimental period; $\square$ No treatment.

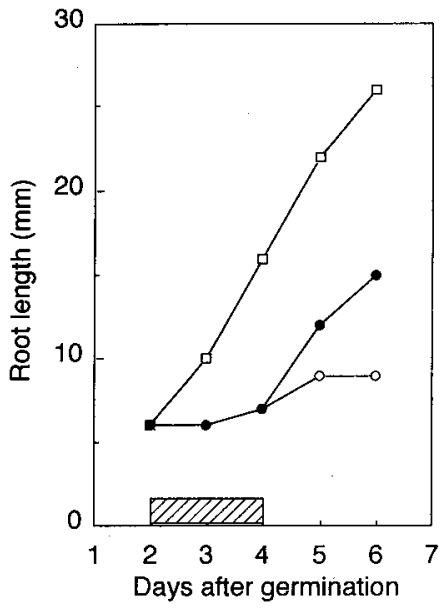

Fig. 7.

(A) Effect of 1 to $N$. rustica.

Bars represent the number of leaves; circles represent the height of plants.

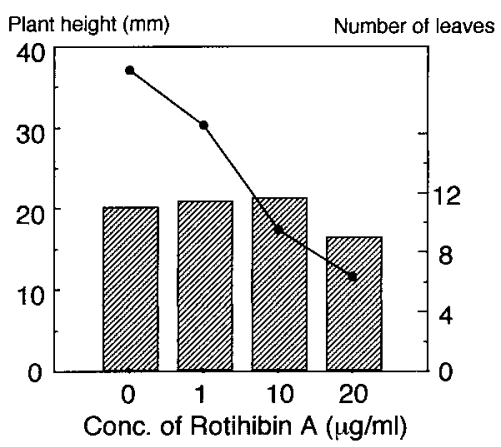

(B) Growth feature of $N$. rustica treated by $\mathbf{1}$.

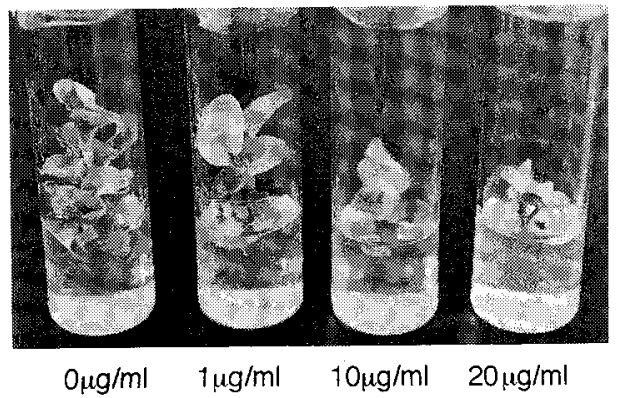

was measured by using shoots with three leaves. The height of $N$. rustica grown on the medium with 1 at above $10 \mu \mathrm{g} / \mathrm{ml}$ was obviously shortened after 30 days' treatment, but there is no differences statistically in the number of leaves (Fig. 7).

\section{Discussion}

In the screening search for plant growth regulators, new plant growth regulators, rotihibins, were discovered. Structural studies revealed that rotihibins were novel lipo-peptidal compounds, and biological studies clarified their specific activity against plants. Rotihibin A (1) not only inhibited the growth of seedlings, but also dwarfed the plants, for example $N$. rustica, at low concentration. It may be possible to utilize $\mathbf{1}$ as a growth retardant.

Although many lipo-peptides found from microbial origin show antitumor, antibacterial and antifungal activity, rotihibin $\mathrm{A}(\mathbf{1})$ does not show any effect on mammalian cells, bacteria or fungi, but only against plants. It is interesting that $\mathbf{1}$ seems to act as a plant hormone, although it is not a plant hormone mimetic.

\section{Experimental}

The UV spectrum was measured with a SHIMADZU UV-160 spectrometer and the IR spectrum was measured with a JASCO A-202. The NMR spectra were measured with a JEOL-JNM GX-400 and a Bruker AM-600 spectrometer. High resolution FAB mass spectra were measured with a JEOL JMS-SX102 and mass/mass spectra were performed on a JEOL JMS-SX102/SX102 spectrometer.

Isolation of Rotihibin A (1) and B (2)

S. graminofaciens 3C02 was cultured in Bennett's medium ${ }^{5}$, which was consisted of $1 \%$ glucose, $0.2 \%$ polypeptone, $0.1 \%$ meat extract and $0.1 \%$ yeast extract (pH 7.2) at $26^{\circ} \mathrm{C}$ for 4 days. The culture filtrate was adsorbed on Amberlite XAD-7 column $(4.0 \times 40 \mathrm{~cm})$, washed with distilled water (1.5 liter) and was eluted with $50 \%$ methanol ( 2 liter). The methanolic eluate, after being concentrated to $200 \mathrm{ml}$ volume and adjusted to $\mathrm{pH} 3.5$ with acetic acid, was applied to SP-Sephadex C-25 cation ion-exchange column and was eluted with each $280 \mathrm{ml}$ volume of $50 \mathrm{~mm}$ ammonium acetate buffer $\mathrm{pH} 4.0,6.0$ and 8.0, successively, and was fractionated. The activity was recovered in the last $60 \mathrm{ml}$ fractions of the $\mathrm{pH} 6.0$ eluate and the first $90 \mathrm{ml}$ of $\mathrm{pH} 8.0$ fractions. After lyophilization, the residue was dissolved in water and charged on the HPLC with ODS column (SSC-ODS-742, $10 \times 250 \mathrm{~mm}$ ), eluted by $0.1 \%$ TFA with acetonitrile/ water linear gradient system ( $0 \%$ to $30 \%$ in 15 minutes) yielding rotihibin A (1) (52.9 mg) and B (2) (trace amount) as an amorphous powder.

\section{Amino Acid Analysis of $\mathbf{1}$}

Rotihibin A (1) (100 mg) was hydrolyzed in PICOTAG workstation (Waters Co.) by constant boiling point $6 \mathrm{~N} \mathrm{HCl}$ (Pierce Chemical Co.) for 22 hours at $110^{\circ} \mathrm{C}$. After removal of $\mathrm{HCl}$ from the hydrolysate under reduced pressure, the residue was dissolved in $20 \mathrm{~mm} \mathrm{HCl}$ $(200 \mathrm{nmol} / \mathrm{ml})$ and applied on amino acid analyzer (HITACHI model-835). 
Edman's Degradation of 1

Rotihibin A (1) (500 mg), evaporated in a glass micro tube, was dissolved in $50 \%$ pyridine $(100 \mu \mathrm{l})$ and added by phenylisothiocyanate (PITC) $(10 \mu \mathrm{l})$, purged by $\mathrm{N}_{2}$ and reacted at $57^{\circ} \mathrm{C}$ for 15 minutes. After evaporation, the dried sample was added by TFA $(20 \mu \mathrm{l})$ and reacted at $57^{\circ} \mathrm{C}$ for 15 minutes, and yielded anilynothianolyzin(ATZ-) derivatives. After removal of TFA, ATZ-derivatives were extracted in ethylacetate $(80 \mu \mathrm{l})$ from water phase $(50 \mu \mathrm{l})$ and dried ATZ-derivatives was reacted with $25 \%$ TFA $(30 \mu \mathrm{l})$ at $55^{\circ} \mathrm{C}$ for 10 minutes yielding PTH-amino acids. Water phase was applied to next Edman's degradation cycle. A part of PTH-amino acids was analyzed by HPLC with ODS column (SSC-ODS$1251-\mathrm{K}, 4.6 \times 250 \mathrm{~mm}$ ) eluted by $0.1 \%$ TFA with acetonitrile/water $(15 \%$ to $50 \%$ in 30 minutes). The retention time of the $\mathrm{PTH}$-amino acid in the first cycle coincided not to PTH-threonine but to PTH-allothreonine. FD mass spectrum of PTH-derivative in the first cycle gave $\mathrm{M}^{+}$ion at $m / z 236$.

\section{Determination of Stereochemistry}

Configurational determination of the amino acids was performed by Marfey's method. Hydrolysate of $\mathbf{1}$ was obtained as mentioned above. A $50 \mathrm{~mm}$ amino acid mixture $(10 \mu 1)$ with $6 \%$ triethylamine $(4 \mu \mathrm{l})$ and $1 \%$ $\mathrm{N}$-(3-fluoro-4,6-dinitrophenyl)-L-alaninamide (FDAA) in acetone $(20 \mu \mathrm{l})$ were reacted at $40^{\circ} \mathrm{C}$ for 1 hour in polypropylene microtube. The reactant was diluted into water $(1 \mathrm{ml})$, and aliquot of the solution $(200 \mathrm{pmol}$ for each amino acid) was applied to HPLC analysis with ODS column (SSC-ODS-1151-N, $4.6 \times 150 \mathrm{~mm}$ ). For separation of basic amino acid derivatives, $10 \mathrm{~mm}$ triethylamine-phosphate buffer (pH 3.0) with acetonitrile/water gradient $(16 \%$ to $30 \%$ in 18 minutes and $30 \%$ to $50 \%$ in 12 minutes) was used as solvent system, and for other amino acids, $10 \mathrm{~mm}$ acetic acid-sodium acetate buffer $(\mathrm{pH} 6.5)$ with acetonitrile/water gradient $(0 \%$ to $10 \%$ in 10 minutes, $10 \%$ to $20 \%$ in 15 minutes, $20 \%$ to $31.5 \%$ in 7 minutes and $31.5 \%$ to $50 \%$ in 2 minutes). FDAA derivatives of amino acids were detected by their absorbance at $340 \mathrm{~nm}$.

Synthesis of L-3-Amino-4-hydroxy-1-butanoic acid (L-Aspol; 3) and DL-Aspol

Methanolic solution $(15 \mathrm{ml})$ of t-butyloxycarbonylasparagine (t-Boc-Asn) $(500 \mathrm{mg})$ was added dropwisely by diazomethane in ether $(20 \mathrm{ml})$ and evaporated. Residual solid was dissolved in hexane - ethylacetate $(3: 7 \mathrm{v} / \mathrm{v})$ and was purified by a silica gel column (Wacogel C-100, $100 \mathrm{ml}$ ), then t-Boc-Asn methyl ester (4) was obtained in hexane - ethylacetate $(1: 9 \mathrm{v} / \mathrm{v})(160 \mathrm{ml})$ and ethylacetate eluate $(160 \mathrm{ml})$ as a white solid $(390 \mathrm{mg})$. Anhydrous THF solution $(20 \mathrm{ml})$ of $4(390 \mathrm{mg})$ was added by $\mathrm{LiBH}_{4}$ and was stirred at room temperature for 20 hours. After degradation of $\mathrm{LiBH}_{4}$ by water, the reactant was applied to silica gel column (Wacogel C-100, $50 \mathrm{ml}$ ) and was eluted by ethylacetate and ethylacetate-methanol (95:15 $\mathrm{v} / \mathrm{v})$. In the later fraction, $\mathrm{L}-\mathrm{N}$-t-butyloxycarbonyl-4amino-3-hydroxybutanamide (t-Boc-Asnol, 5) was recovered $(54 \mathrm{mg})$. Hydrolysis of 5 by constant boiling point $6 \mathrm{~N} \mathrm{HCl}\left(110^{\circ} \mathrm{C}, 22\right.$ hours $)$ yielded L-Aspol (3): ${ }^{13} \mathrm{C}$ NMR $\left(75 \mathrm{MHz}, \mathrm{CD}_{3} \mathrm{OD}\right) \delta 28.7\left(3 \times \mathrm{CH}_{3}\right), 38.3$ $\left(\mathrm{CH}_{2}\right), 51.3(\mathrm{CH}), 64.7\left(\mathrm{CH}_{2}\right), 80.2(\mathrm{C}), 157.8(\mathrm{CO})$ and $176.4(\mathrm{CO}) ;{ }^{1} \mathrm{H}-\mathrm{NMR}\left(300 \mathrm{MHz}, \mathrm{CD}_{3} \mathrm{OD}\right) \delta 1.49(9 \mathrm{H}$, s), $2.40(1 \mathrm{H}, \mathrm{m}), 2.52(1 \mathrm{H}, \mathrm{m}), 3.58(2 \mathrm{H}, \mathrm{m}), 3.97(1 \mathrm{H}$, $\mathrm{m})$.

DL-Aspol was prepared in a similar way from DLasparagine.

\section{Biological Activity of Rotihibin A (1)}

Cytotoxity of 1 to K 562 cell was measured in RPMI640 medium with $10 \%$ fetal calf serum (FCS), and to FM3A and HSG cells was measured in Dulbeco MEM medium with $10 \%$ FCS. To the media with each cells, $50 \%$ methanol solution of 1 was added. Each cells were seeded to the media at $1 \times 10^{5}$ cells $/ \mathrm{ml}$ in 96 well plate. After the culture at $37^{\circ} \mathrm{C}$ under humidified atmosphere in $\mathrm{CO}_{2}$ incubator for 4 days, the cell number was counted.

Antimicrobial activity of $\mathbf{1}$ was measured by observing inhibition circles on the agar plates seeded by the test bacteria and fungi and put by the paper disks with sample solution.

Lettuce seedling test was performed by incubating ten lettuce seeds in $5 \mathrm{~cm}$ diameter petri dishes containing filter papers and Murashige-Skoog's medium with sample. The petri dishes were incubated under 3000 lux white light at $30^{\circ} \mathrm{C}$ for 4 days and the length of roots was measured.

Inhibitory activity on Nicotiana rustica was measured as below. The shoot with three leaves of $N$. rustica grown to $6 \sim 7$ leaves height was cut off and cultured on Murashige-Skoog's medium (Nihon Seiyaku Co.) with $0.2 \%$ gelan gum in a glass tube. The medium was added by filtered solution of 1 after autoclave. After 30 days of culture at $25^{\circ} \mathrm{C}$ under 3000 lux of white continuous light, the length of shoot and the number of leaves were counted.

\section{Acknowledgments}

We thank to Mr. K. NoJima of JEOL Ltd. for the measurement of the high-resolution FAB mass spectra, Dr. T. Nishimura of the University of Tokyo for the amino acid analysis and Dr. S. MATSUNAGA of the University of Tokyo for authentic samples of amino acids. This work was supported in part by a Grant-in-Aid for Scientific Research from the Ministry of Education, Science and Culture of Japan.

\section{References}

1) Fukuchi, N.; K. Furihata, S. Takayama, A. Isogai \& A. SuzukI: Rotihibin A, a novel plant regulator, from Streptomyces sp. Biosci. Biotech. Biochem. 56: 840 841, 1992

2) Fukuchi, N.; J. Nakayama, S. Takayama, A. Isogai \& A. SuZuKI: Structural elucidation of rotihibin $B$ by tandem mass spectrometry. Biosci. Biotech. Biochem. 56: 
$1152 \sim 1152,1992$

3) YamaGUCH, T.: Comparison of the cell-wall composition of morphologically distinct actinomycetes. J. Bacteriol. 89: 444 453, 1965

4) Pridham T. G. \& H. D. Tresner: Genus I. Streptomyces Waksman and Henrici, 1943, 339. In BERGEY's Manual of Determinative Bacteriology. 8th Ed. Eds., R. E. Buchaman \& N. E. Gibbson, pp. $748 \sim 829$, Williams \& Wilkins Co., 1974

5) Shirling, E. B. \& D. Gottlieb: Methods for characterization of Streptomyces species, Int. J. Syst. Bacteriol. 16: $313 \sim 340,1966$

6) BAX, A. \& M. F. Summer: ${ }^{1} \mathrm{H}$ and ${ }^{13} \mathrm{C}$ assignments from sensitivity-enhanced detection of heteronuclaer multiplebond connectivity by 2D multiple quantum NMR. J. Am. Chem. Soc. 108: 2093 2094, 1986

7) Bax, A. \& S. Subramanian: Sensitivity-enhanced two-dimensional heteronuclaer shift correlation NMR spectroscopy. J. Magn. Reson. 67: 565 569, 1986

8) Biemann, K.: Contributions of mass spectrometry to peptide and protein structure. Biomed. Environ. Mass Spectro. 16: 99 111, 1988

9) MARFEY, P.: Determination of D-amino acids. II. Use of a bifunctional reagent, 1,5-difluoro-2,4-dinitrobenzene. Carlsberg Res. Commun. 49: $591 \sim 596,1984$ 